\title{
Od stereotypu do wykluczenia, red. Anna Fidelus, Wydawnictwo Uniwersytetu Kardynała Stefana Wyszyńskiego, Warszawa 2014, ss. 227.
}

Nowością na rynku wydawniczym jest publikacja pt. Od stereotypu do wykluczenia, napisana pod redakcją naukową dr hab. Anny Fidelus, prof. UKSW. Zawiera wstęp, osiem opracowań naukowych oraz bibliografię. Treści w niej zawarte dotyczą stereotypu i jego związku z wykluczeniem społecznym. Istniejące w świadomości ludzkiej stereotypy na temat poszczególnych osób, a czasem nawet całych grup społecznych, powodują wykluczenie z życia społecznego jednostek naznaczonych krzywdzącymi opiniami na ich temat. W pierwszych sześciu rozdziałach przedstawiona jest sytuacja poszczególnych grup zagrożonych wykluczeniem społecznym i podane są przykłady stereotypowego do nich podejścia. $Z$ kolei w dwóch ostatnich zostały omówione konkretne rozwiązania zmierzające do ograniczenia zjawiska stereotypizowania, jak również wykluczenia społecznego. Publikacja zawiera artykuły napisane przez Kingę Krawiecką, Marzenę Dycht, Emilię Śmiechowską-Petrovskij, Martynę Żelazkowską, Mariusza Gajewskiego, Marlenę Kilian, Beatę Krajewską i Annę Fidelus.

Kinga Krawiecka w rozdziale pt. Stygmatyzacja osób z niepetnosprawnościa intelektualna a rzeczywistość teatralna przedstawia sytuację ludzi z niepełnosprawnością intelektualną zagrożonych wykluczeniem społecznym. Prezentuje przypisywane im stereotypowe cechy, które są krzywdzące i ukazują ich w niewłaściwym świetle. Autorka zaznacza, że stygmatyzacja społeczna osób z niepełnosprawnością intelektualną powoduje negatywne konsekwencje dla jednostki obarczonej omawianą niepełnosprawnością, może ona m.in. wycofać się z kontaktów z innymi ludźmi, być agresywna bądź roszczeniowa. Krawiecka opisuje znaczenie sztuki, a dokładniej teatru, w przeciwstawianiu się stereotypowemu postrzeganiu jednostki z niepełnosprawnością intelektualną. Sama współtworzy teatr osób z taką niepełnosprawnością i dzieli się własnymi doświadczeniami ze swojej pracy. Ukazuje, jak działalność teatralna czyni te osoby szczęśliwymi. Kinga Krawiecka zachęca do twórczego działania z osobami z niepełnosprawnością intelektualną w celu eliminowania istniejących stereotypów na ich temat. 
Marzena Dycht w rozdziale pt. Mity, uprzedzenia, stereotypy a zjawisko piętna i stygmatyzacji niepełnosprawnych wzrokowo pokazuje sytuację osób niepełnosprawnych wzrokowo w kontekście zagrożenia wykluczeniem społecznym. Autorka przedstawia szereg badań dotyczących stereotypizacji osób niepełnosprawnych. Obala także mity, które funkcjonują w społeczeństwie na temat osób niewidomych i słabowidzących. Marzena Dycht podkreśla znaczenie mass mediów w kreowaniu prawdziwego wizerunku osób niepełnosprawnych wzrokowo. Ukazywanie ich w mediach jako radosnych, samodzielnych, zdolnych do wykonywania pracy zawodowej powoduje zmniejszenie stygmatyzacji, a tym samym zapobiega wykluczeniu społecznemu. Autorka ukazuje kampanie społeczne jako przykład przeciwstawiania się społecznej stygmatyzacji osób niewidomych i słabowidzących. Dzięki nim wzrasta w społeczeństwie wiedza na temat tego, jak funkcjonują osoby niepełnosprawne wzrokowo, a także pokazywany jest rzeczywisty wizerunek tej grupy społecznej. Autorka podaje przykłady dyskryminacji osób niepełnosprawnych (w edukacji, dostępie do informacji, w sektorze zatrudnienia i na rynku pracy), a także formy minimalizowania tego zjawiska. Zwraca uwagę na przepisy prawne dotyczące niepełnosprawnych, które wymagają zmian legislacyjnych, by doprowadzić do poprawy jakości życia tych osób.

Następny rozdział, autorstwa Emilii Śmiechowskiej-Petrovskij, zatytułowany Aspekty stygmatyzacji i stereotypizacji osób niewidomych oraz tendencje przeciwstawne, także prezentuje osoby niewidome jako grupę narażoną na wykluczenie społeczne. Autorka zaznacza, że jest to spowodowane błędnymi przekonaniami i negatywnym stosunkiem społeczeństwa wobec osób niewidomych, co może być wynikiem podzielania funkcjonujących stereotypów. Emilia Śmiechowska-Petrovskij porusza problem obniżania wartości osób niewidomych poprzez takie kanały przekazu jak: mowa potoczna, dyskurs naukowy, podręcznik szkolny, przedstawienie medialne. Pisze, jak przez zniekształcony wizerunek niepełnosprawnych wzrokowo w mediach utrwalają się stereotypy na ich temat. Autorka zwraca uwagę, że język (utrwalone w nim negatywne słownictwo i frazeologia na temat niepełnosprawności, w tym wzrokowej) okazuje się zbiorem społecznych mitów i stereotypów dotyczących osób z niepełnosprawnością. Śmiechowska-Petrovskij zauważa też związek pomiędzy prezentowanym w podręcznikach szkolnych obrazem osób niewidomych a postrzeganiem tych osób przez dzieci w młodszym wieku szkolnym. Podkreśla, jak ważne jest, aby w podręcznikach szkolnych zawarte były prawdziwe informacje na temat niepełnosprawnych. Wymienia też działania, które są podejmowane w celu ukazania prawdziwego obrazu ludzi niepełnosprawnych wzrokowo, a także wpływają na poprawę ich sytuacji życiowej.

Martyna Żelazkowska w rozdziale pt. Wykluczenie społeczne samotnych matek współczesnym problemem edukacyjnym koncentruje się w swych rozważaniach na problematyce samotnego macierzyństwa. Autorka zauważa, że kobiety samotnie wychowujące swoje dzieci, które są bez pracy lub mają niskie dochody, a w związku z tym nie mogą zaspokoić potrzeb swoich i dziecka, oraz nie otrzymują wsparcia 
ze strony bliskich osób, narażone są na zepchnięcie na margines życia społecznego. Martyna Żelazkowska podaje sposoby pomocy i wsparcia tej grupy kobiet. Podkreśla, jak ważna jest prewencja w celu zmniejszania skali tego zjawiska, a także pomoc o charakterze indywidualnym, instytucjonalnym i systemowym. Zaznacza, że istotne jest eliminowanie uprzedzeń wobec tej grupy społecznej.

Rozdział zatytułowany Marginalizacja i wykluczenie społeczne kontrowersyjnych grup kultowych i ich adeptów - społeczne uwarunkowania zjawiska autorstwa Mariusza Gajewskiego zwraca uwagę na marginalizację i wykluczenie społeczne grup kultowych, a także osób przynależących do tych społeczności. To zjawisko spowodowane jest z jednej strony dbałością o zachowanie zasad i wartości społecznie akceptowanych, a $\mathrm{z}$ drugiej związane jest $\mathrm{z}$ istniejącymi wobec tej grupy uprzedzeniami i lękiem. Ciekawy jest fakt, że osoby należące do grup kultowych same wykluczają się z kręgu życia społecznego. Ten przejaw dogłębnie w swojej pracy analizuje Gajewski. Autor naświetla także niebagatelny problem dzieci i młodzieży, których rodzice przynależą do grup kultowych i w związku z tym narażone są one na izolację od społeczeństwa. Mariusz Gajewski podkreśla znaczenie tworzenia programów profilaktycznych dotyczących sekt w celu chronienia dzieci przed ich manipulacyjną działalnością.

W rozdziale Starość nie radość. Skutki stereotypizacji starszego wieku Marleny Kilian poruszany jest ważny problem dyskryminacji i stereotypizacji osób starszych. Autorka ukazuje, jak zjawisko ageizmu negatywnie wpływa na funkcjonowanie fizyczne, psychiczne i społeczne ludzi w podeszłym wieku. Prezentuje osobę w starszym wieku jako produktywną i posiadającą potencjał, przełamując przy tym stereotypy na temat wieku senioralnego. Uświadamia też, jak ważna jest zmiana podejścia do osób w podeszłym wieku i że mogłaby się ona przyczynić do lepszej ich egzystencji.

Kolejny rozdział, autorstwa Beaty Krajewskiej, zatytułowany Asystenci rodziny wobec dzieci i rodzin zagrożonych wykluczeniem społecznym, przedstawia asystenta rodziny jako podmiot wspierający dzieci i rodziny, w których panuje bieda, bezrobocie, a rodzice nie są wstanie zaspokoić potrzeb swoich dzieci i zapewnić im należytej opieki. Rodziny, w których dominuje ubóstwo i brakuje perspektyw, zagrożone są marginalizacją czy wykluczeniem społecznym. Autorka podkreśla rolę i znaczenie asystenta rodziny jako osoby, która udziela pomocy rodzinom wymagającym interwencji i tym samym przyczynia się do ich inkluzji społecznej. Beata Krajewska szczegółowo prezentuje zadania i działania, jakie stoją przed asystentem rodziny.

Książkę zamyka tekst Anny Fidelus pt. Społeczność lokalna jako płaszczyzna działań zapobiegających wykluczeniu społecznemu byłych więźniów. Autorka podejmuje w nim kwestię sytuacji skazanych powracających z zakładu karnego do otoczenia społecznego. Zauważa, że osoby te narażone są na wykluczenie ze środowiska społecznego w związku z istniejącymi czynnikami utrudniającymi proces readaptacji społecznej osoby skazanej, są to m.in. stygmatyzacja, trudności 
związane ze znalezieniem pracy oraz brak wsparcia ze strony rodziny. Profesor Fidelus skupia się w swych rozważaniach na roli społeczności lokalnej, która ma za zadanie zapobiegać ekskluzji byłych więźniów. Stwierdza, że środowisko lokalne (ludzie, instytucje) powinno pomóc byłemu skazanemu w procesie społecznej readaptacji. Podkreśla, że sytuacja byłych więźniów jest problemem społecznym w danej społeczności lokalnej, ale jednocześnie poddaje w wątpliwość fakt, czy rzeczywiście tak jest i czy osoby pracujące w instytucjach dostrzegają problem, jakim jest sytuacja życiowa byłych skazanych, oraz zauważają konieczność jego rozwiązania. Analizując te zagadnienia, dochodzi do wniosku, że nie ma na nie jednoznacznych odpowiedzi. Anna Fidelus wymienia czynniki, które wpływają na to, czy osoba skazana powracająca do środowiska społecznego otrzyma pomoc od drugiego człowieka, są to: osobiste doświadczenia kontaktu ze skazanymi, wiedza na temat problemów skazanych, a także poglądy osób znaczących w danej społeczności, które mają wpływ na opinię publiczną, np. polityków, duchownych.

Recenzowana monografia porusza ważny problem, jakim jest wykluczenie społeczne. Autorzy poszczególnych rozdziałów ukazują grupy społeczne, które zagrożone są wykluczeniem ze środowiska społecznego z powodu istniejących w przestrzeni publicznej stereotypów na ich temat. Cenne jest to, że podane są działania, jakie należy podejmować w celu eliminacji stereotypów dotyczących omawianych grup społecznych, a także formy pomocy tym osobom. Podjęte w książce zagadnienie zostało omówione przez osoby reprezentujące różne dziedziny nauki, tj. pedagogikę, psychologię, filozofię. Niniejsze opracowanie podkreśla, jak ważne jest traktowanie jednostek wykluczonych lub zagrożonych wykluczeniem społecznym jako pełnoprawnych członków społeczeństwa. Publikacja adresowana jest do pedagogów, pedagogów specjalnych, pracowników socjalnych, socjologów i polityków społecznych. Pozycję tę można polecić także studentom kierunków humanistycznych i społecznych. Ze względu na aktualną problematykę, która dotyczy osób żyjących w zbiorowości społecznej, jest wartościowym źródłem informacji dla każdego.

Małgorzata Mróz

UKSW, Warszawa 